\title{
'The experts taught us all we know': Professionalisation and Knowledge in Nepalese Community Forestry
}

final version of this manuscript appears in:

Antipode, Volume 37, Issue 3, Page 581-604, Jun 2005

Andrea J. Nightingale

Geography, School of GeoSciences;

University of Edinburgh;

Edinburgh EH8 9XP

anightin@geo.ed.ac.uk 


\section{Copyright}

This online paper may be cited in line with the usual academic conventions. You may also download it for your own personal use. This paper must not be published elsewhere (e.g. mailing lists, bulletin boards etc.) without the author's explicit permission

Please note that :

- $\quad$ it is a draft;

- $\quad$ this paper should not be used for commercial purposes or gain;

- you should observe the conventions of academic citation in a version of the following or similar form:

Andrea J. Nightingale (2006) 'The experts taught us all we know': Professionalisation and Knowledge in Nepalese Community Forestry, online papers archived by the Institute of Geography, School of Geosciences, University of Edinburgh. 


\section{Acknowledgements}

\section{Abstract}

Environmentalist concerns over the state of Nepal's 'fragile forests' resulted in the establishment of Community Forestry projects. These community-based projects are partnerships between the state and community user-groups that invest user-groups with a great deal of control over their forests. Project implementation, however begins with the assumption that users have little prior knowledge of forest management and need to be taught modern silviculture. This paper examines the extent to which different community members embrace notions of professional forestry materially and symbolically. The development of written management plans, the need for careful accounting records and the promotion of silviculturally based management strategies by District Forest Officers serve to (re)inscribe differences between users based on education and literacy. Which users embrace these discourses and practices and for what purposes lends insight into the workings of neo-liberalism and how it is implicated in the reconfiguring of social and power relations within localities and in this case, the consequences of this for ecological change. It is argued that the promotion of expert knowledge and professional practices in Community Forestry is often used as a somewhat contradictory vehicle for educated elites to retain control over forest management thus undermining some of the key objectives of the program.

Keywords: professionalisation, neo-liberalism, Community Forestry, Nepal, knowledge 


\section{Introduction}

Neo-liberalism is an elusive concept and, as its usage has become more prevalent in policy and academic circles, it has come to stand for an increasingly wide range of market-society relations. This paper places the daily practices of development and negotiations over power and knowledge into an analysis of neo-liberalism. Using the example of community forestry in Nepal, I seek to illustrate how neo-liberalism is constituted and contested in localities and thus takes specific forms in particular places (Scott, 1998, Sivaramakrishnan and Agrawal, 2003, Watts, 2003, Rankin, 2001).

My purpose here is to contribute to work done more explicitly on the economic aspects of neo-liberalism in Nepal by investigating how its ideological features are increasingly prevalent within environment-development programmes (Peck and Tickell, 2002, Laurie et al., 2003, Rankin, 2001, Watts, 2003). In Nepal, one key change has been a move from promoting technology transfer to the promotion of particular kinds of knowledges. Many programs aim to facilitate the 'diffusion of knowledge' or encourage new 'knowledge-regimes' which are assumed to culminate in development (Adams, 1990, Crush, 1995, Escobar, 1995, Sivaramakrishnan and Agrawal, 2003). As a result, many development practitioners seek to teach new skills to what are perceived to be backward populations and localities. Community forestry $(\mathrm{CF})$ in Nepal is no exception and the programme is rife with mechanisms to promote learning in relation to forest conservation and scientific forestry.

Wendy Larner (2000) has distinguished three-types of scholarship on neo-liberalism. First, work which explores neo-liberalism as a policy framework; second, research 
which focuses on the ideological aspects; and third, that which examines it as a form of governmentality. All of these approaches assume neo-liberalism is characterised by the scaling back of the welfare state in Post-Fordist capitalism and a privileging of market forces to organise social-political-economic life (Larner, 2000\{Jessop, 2002 \#874) \}. The economy of Nepal cannot be characterised as 'Post-Fordist' as it has not gone through a Fordist stage, but rather, like many developing countries, has features of both feudal and capitalist relations of production characteristic of so-called 'transition' economies (de Janvry, 1981, Jessop, 2002, Rankin, 2004). While systematic studies of the impact of neo-liberalism on the development process in Nepal have not been done, through Structural Adjustment and other economic programmes, aspects of neo-liberal orthodoxy can be identified in the current political-economy of Nepal (Rankin, 2004, Rankin, 2001).

Here I want to distinguish between neo-liberalism as an economic programme and neo-liberalism as a set of ideas about the appropriate mechanisms for social and economic progress (Peck and Tickell, 2002). While neo-liberalism is difficult to neatly separate from processes of modernisation or post-colonialism (Hart, 2002), I am interested in exploring aspects of the modernisation process that have been shaped by neo-liberalism. The need to examine the daily practices of development and neoliberalism and how these are linked to knowledge has been discussed by a number of authors (Gupta, 1998, Agrawal and Sivaramakrishnan, 2000, Escobar, 1995, Sivaramakrishnan and Agrawal, 2003, Peck and Tickell, 2002, Watts, 2003). This work explores the embedding of professionalism, the promotion of individuals as agents of development, and market relations as they are constituted through processes of globalisation and economic change (Peck and Tickell, 2002, Watts, 2003). In 
particular, I emphasise two key strands that are often seen to define neo-liberalism as a mechanism of change: one, the promotion and embedding of professional and expert knowledges within a range of services and activities; and two, the valorisation of market and quasi-market relations across a range of social and political arenas. Community forestry in Nepal is in many respects in direct opposition to these processes of neo-liberalism because of its emphasis on collective practices, and yet nevertheless, has become an arena within which these ideologies are appropriated, contested and entrenched.

Economic processes of globalisation have only somewhat tangential effects on remote areas of Nepal, but the impact of neo-liberalism is experienced in at least three ways. First, in the assumption that there is a distinction between local and professional knowledge (see also Gururani, 2000, Sivaramakrishnan and Agrawal, 2003). This is often manifest in the emphasis on teaching villagers proper, scientific, forest management. Second, there is an emphasis on implementing programmes that decentralise state control by turning over forests and local development to villagers. Third, development programmes such as community forestry are important arenas within which key social relations, particularly around caste and gender are (re)inscribed. Community forestry thus also needs to be recognized as constitutive of neo-liberalism as the programme itself is embedded within overall development ideologies and through its enactment, what 'neo-liberalism' means within specific localities is produced.

Before elaborating on how neo-liberalism is manifest within developmentenvironment programmes in Nepal, a bit of background on community forestry will 
help to contextualise the following discussion. Forests in Nepal provide crucial inputs to agro-forestry systems in the form of leaf litter, fodder for animals and firewood for cooking. Their apparent degradation has been the focus of international attention since the early 1970s and a number of programmes have been instituted to reverse degradation in what are perceived to be dangerously fragile mountain ecosystems (Graner, 1997, Gilmour and Fisher, 1991). The most visible of these programmes is community forestry, a government and foreign donor-sponsored programme that turns the management of forests over to village user-groups. Legally villagers are given responsibility for the daily management and oversight of their forests and are allowed to set restrictions on the harvesting and sale of forest products. The statutory authority, the District Forest Office (DFO), however, denies the groups collective choice rights (cf. Ostrom, 1992, Arnold, 1998), in other words, the villagers are not able to change their management strategies without the approval of the DFO staff. In order to take over the management of a community forest, a user-group must first map the forest and develop an operational plan (OP) (Shrestha et al., 1995). The District Forest Office staff and where relevant, foreign-donor project staff, provide substantial assistance to user-groups during this phase. Once the forest has been surveyed, mapped and the operational plan is approved, the amount of assistance villagers are given for the daily functioning of their management committees is highly variable. Foreign-donor sponsored groups tend to receive substantial assistance, whereas others, like the groups I worked with in Mugu District of northwestern Nepal, receive very little.

To understand the contradictory embedding of neo-liberalism in rural Nepal (cf. Jessop, 2002, Larner, 2000), I explore the ways that the professionalisation of forestry 
in Nepal authorises particular kinds of knowledges, discourses and practices related to forest management. Issues of who has knowledge, who needs to be taught and what they are taught are central to contestations over who can be legitimate managers of natural resources and what information they need to be effective. Knowledge intersects with the promotion of quasi-market relations and idealised visions of 'community', (closely linked to key political changes), to re-figure caste and gender relations, although in this paper I focus primarily on caste relations. Which users embrace the discourses and practices of professionalism and for what purposes lends insight into the workings of neo-liberalism and how it is implicated in the reconfiguring of social and power relations within localities and in this case, the consequences of this for ecological change.

I argue that the promotion of scientific forestry practices potentially undermines three of community forestry's key objectives: to include the poorest of the poor, to promote democratic institutions to manage forests, and to promote forest ecosystem health. While in some sense, these objectives are counter to the goals of neo-liberalism, especially those that seek to foster competitive market relations to stabilise social and economic inequalities, the programme can also be seen to be embedded within a neoliberal logic of property relations that seeks to privatize common resources through the promotion of collective management (Mansfield, 2004). As Mansfield (2004) has argued, the promotion of common resources as 'property' is firmly situated within a neo-liberal logic that assumes rational, profit seeking economic subjectivities and thus the need to regulate use of resources through property arrangements. Key to these ideas within community forestry is the vision of a recognisable and un-contetsted 'community' to which management of forests can be given. In the case that follows, 
the disputes I recount show the complex appropriations and resistances to these neoliberal subjectivities and reveal the contested nature of 'the community'. Similar complexities are evident in the ways in which the re-figuring of caste and gender are the outcome of these resistances, appropriations and acquiescence of neo-liberal forms of knowledge and quasi- market relations. This analysis of a programme designed to empower local people therefore helps to illustrate some of the internal contradictions of neo-liberalism. The programme offers possibilities to contest neo-liberal social and power relations and take control over crucial resources, but these opportunities also serve to further entrench discourses of development and professionalisation into the daily practices of forest use. As such, the programme undermines immediate state control over natural resources, yet simultaneously promotes neo-liberal notions of property and 'professional' subjectivities that strengthen state control from afar, serving to entrench particular neo-liberal ideologies into the most remote places of Nepal.

The establishment of District Forest Offices was one of the first steps in the process of professionalisation in the forestry sector of Nepal (Bhattarai et al., 2002). The offices brought professional foresters into all areas of Nepal but beyond attempts at enforcing national forest rules ${ }^{\mathrm{i}}$, they had little contact with villagers. Community forestry, in contrast, is a programme that gives villagers control over the management of their forests with input from the District Forest Officer and the staff of rangers. Through this input, community forestry can be seen as a vehicle for expanding neo-liberal notions of 'professional', community and scientific forestry into villages all across Nepal and yet also a key mechanism through which villagers are able to resist aspects of scientific logic and state control. 
To explore how neo-liberalism shapes subjectivities within community forestry, I draw from feminist theory and discourse analysis to look at how people's subjectivities are linked to the mobilisation of particular discourses. Feminist theories of subjectivity have examined the ways in which people internalise different identities such as gender, caste, class, but also more subtle forms of social hierarchy and oppression (Butler, 1997, Nightingale, forthcoming, Mahoney and Yngvesson, 1992, Mehta and Bondi, 1999). In this kind of conceptualisation, identities are not assumed to be linked to pre-given characteristics but rather are the result of social interactions. Thus the meanings and significance of gender and caste are not static or stable but rather are performed, (re)defined and (re)negotiated in daily interactions (Butler, 1990, Butler, 1992, Bondi and Davidson, 2004). A key insight from this work is that many forms of resistance require people to first internalise their oppressed status (Mahoney and Yngvesson, 1992). In other words people are able to draw on dominant discourses of social difference in order to contest their status within them or to draw into question the discourse itself. Yet by doing so, they must first acknowledge and internalise that discourse as dominant and thus (re)produce it. In the context of community forestry, I examine how people draw on scientific knowledge in order to assert authority, but in a more complex dynamic, I also explore how people use a lack of scientific knowledge to exert power and the importance of their own knowledge. How and when social hierarchies become salient in natural resource management lends insight into how neo-liberal processes of professionalisation, knowledge and legitimate rights to manage the forest are embedded within power relations and the daily practices of forest use. In short, we see aspects of neo-liberalism and the contestation of it in action. 


\section{Community Forestry in Mugu}

I worked with a user-group that was formed in 1991 and had their operational plan approved in 1993, allowing the forest (named Pipledi) to be officially handed over to them. They have been responsible for managing it with some oversight from the DFO ever since. ${ }^{\text {ii }}$ The mixed-caste group consists of four different castes: highest-caste Brahmins and Thakuris, middle caste Chhetris and lowest-caste (or so called 'untouchable') Kamis. In this part of Nepal, caste and gender continue to be very significant social relations that shape the division of labour as well as a variety of spatial and bodily practices associated with ritual pollution. The relationships between work, caste, gender, labour relations and class are very complex, but I provide a brief outline here. Some of these relationships will become clearer throughout the paper.

Work is a key domain within which social differences are defined and maintained and thus is a symbolic as well as material enactment of social power. Due to bodily practices associated with caste and class, high-caste men (Brahmins and Thakuris) are reluctant to do manual labour and when they are wealthy enough, hire low-caste men and women to work their fields. Most of the resources needed on a daily basis, including water, firewood, animal fodder and leaf litter, are thus gathered by women of all castes. Lower-caste men (Chhetri and Kami) also participate in these activities but if they have access to a cash income or any kind of 'office work' they avoid these chores. Working in offices—in Mugu generally government agencies such as the District Forest Office or the handful of foreign-aid sponsored offices ${ }^{\mathrm{iii}}$-requires literacy skills and confers significant social and economic power. Kami men and the 
vast majority of women are essentially excluded from such opportunities both because of their social status and because they are illiterate. A Kami man who had obtained his School Leaving Certificate complained bitterly of the lack of appropriate opportunities for him because of his caste status. Office jobs thus both confer status because of the literacy skills and high-caste status of the men who hold them, and are only available to those who fit that profile. This is one of the important ways in which neo-liberal processes are evident in rural Nepal. Development has become equated with cash incomes and education among other attributes (Pigg, 1996), and significant social and political power can be gained from being developed.

In many respects these processes are not new. Literacy skills have conferred social status and power within Mugu at least since the early twentieth century and perhaps longer. Oral histories indicate that the ancestors of many of the current leaders within the village were educated men who were well aware of and strategically utilised the legal system. The mukiya, or village tax collector and headman, and his brother, a clerk responsible for a variety of legal tasks, were instrumental in obtaining control of Pipledi forest in 1919. Both men were given these positions by the Rana government that ruled Nepal from 1846-1951 and their eldest sons after them expected to continue in those roles. The mukiya has very little power now since he no longer collects taxes, but he is nevertheless given respect and continues to safeguard and interpret old documents that show title to land and importantly for this user-group, forests. Many of the high-caste men in the village are descendent from the mukiya although only direct descendents try to claim political and social power based on their heritage. All of them have been educated at home, therefore only a few adult high-caste men cannot read proficiently. Now, however, with the increasing professionalisation of 
knowledge, having degrees is more important than literacy skills and some people implied that powerful high-caste families have actually paid for their sons' degrees as they were not able to pass the exams.

In addition, neo-liberal processes have led to substantial changes in labour relations. According to oral histories, historically the Chhetris and lower-castes worked for the highest-castes in feudal and bonded labour arrangements until sometime in the second half of the twentieth century. Now the lowest-castes have lands of their own that have very recently been brought under cultivation and they have a variety of wage labour opportunities available to them through state and foreign donor-sponsored building projects in Mugu. As a consequence, the high-caste people complain that the lowcastes do not 'mind' anymore and are slow to come and work their fields for the food and small cash payment that is offered. This has led to significant reconfigurations of work expectations and has served to firmly establish a cash-based economy in Mugu. Until the institution of government offices and various work opportunities for both high and low caste men, the economy in Mugu was largely based on barter and primary production. Now primary production continues to be the main source of subsistence for most people, but cash-based exchanges have replaced many barter and feudal labour relations. In addition, the People's War which brought in multi-party democracy in 1990 (Hoftun et al., 1999), has intersected with these economic changes to reconfigure caste relations in significant ways. Both the high and low-caste people explained that because (high-caste) politicians need the votes of the lowest-castes, they can no longer dominate them to the same extent. Many of my respondents concluded that not much had changed, yet there was an overall sense that at least legally and politically, they were all equal. Thus both the low-castes and high-castes 
are actively involved in appropriating new forms of authority within political and social arenas and community forestry is no exception. Below I detail the ways in which caste hierarchies are mobilised, contested and re-entrenched as an example of the appropriation of and opposition to neo-liberalism (see also Gupta, 1998). ${ }^{\text {iv }}$

In this context it is perhaps not surprising that high-caste men have claimed positions of authority within the community forestry user-group based on caste status and literacy skills. What is more interesting, however, is how literacy, and the knowledge to which it gives certain people access, is contested and mobilised within the usergroup. It is important to highlight here that while literate, high-caste men claim the right to control the user-group and develop management priorities, it is the low-caste, illiterate men and illiterate women of all castes who do the vast majority of the harvesting and other work in the forest.

The relationships between literacy, knowledge and power were well illustrated in a dispute over two houses that had been built within the community forest boundaries by two lowest-caste brothers. The clearing of forest land for agriculture or for building purposes is strictly forbidden by both national forest and community forest rules. The two houses in question were well within the community forest boundaries but perhaps more significantly, their presence had been reported to the District Forest Office leaving the user-group the task of punishing the violators. If the issue had not been reported to the DFO the user-group might have had more flexibility in how they dealt with the issue. As it was, the extent to which they believed they had to follow the operational plan to the letter was central to the conflict and thus the operational plan became a highly contested arena. The operational plan is a legal, binding 
document and if the DFO or the group so chose, they could bring legal proceedings against someone for violating the rules. In practice however, this is highly unlikely, but the document and the threat of legal action is used to force compliance with the rules. In the incident over the houses, people appealed to it in different ways to suit their interests, for example, at one meeting the following discussion took place.

\section{Kami man [angry]}

Who has to pay a fine? We will move the house... After everyone thinks about it, what could happen (ke lagyo)? (i.e. 'what's the big deal'). The committee can decide to take a lot of money or a small amount of money, if the committee decides one can put up a house, whatever the committee decides, that can be done. For this we have the committee, otherwise what [kind of] committee is this?

A Thakuri man looks at the management plan and reads the rules slowly to the Kami men.

Kami man: The government has made these rules, you made [this plan] by looking at the forest regulations, this is something that is in the committee's hands. (CF meeting 19 June 1999).

The Kami man in the above exchange insists that because the rules have been written by the user-group they also have the power to change them. He refuses to take the operational plan as the final authority and rather appeals to the committee as the final authority - a committee of which he considers himself a member. Technically, he is not a committee member, but rather only a user-group member, thus he does not have formal decision making authority but he does have a voice in the process. From his 
perspective, the operational plan is almost meaningless; rather it is the negotiations in the user-group that count. The operational plan is in many ways representative of the state and the authority of the legal system, a system which in their eyes has rarely served the interests of the lower-castes. Perhaps more importantly, it is a system they feel unable to negotiate to their advantage in most circumstances.

The high-caste men, in contrast to the Kami man, view the operational plan as a semisacred authority. They have a very high regard for official documents and they are well familiar with their legal power. When the community forest was formed, the 1919 document that conferred legal control over the forest to the mukiya was critical to establish and legitimate the group's claim to that particular piece of land. Thus the high-caste men approach the operational plan from a very different perspective than the low-caste men and for them, it is often an authority to legitimate their decisions. It is representative of the state, the legal system and other national powers that they in some ways fear, but also seek to keep on their side. It has served them in the past and thus they deliberately cultivate good relationships with the District Forest Office staff and other key government officials in the locality.

The issue was not resolved quickly and at many of the meetings the management plan was brought out and read; sometimes people read it out loud to themselves and at other times out loud to the Kamis, slowly and deliberately at high volume as if reading to a non-native speaker. When reading to the Kami men, the high-caste men often said they needed to teach the Kami men or make them 'aware'. Awareness in Mugu is used as an indicator of being developed and literate (see also Pigg, 1996). The Kamis were thus considered to lack knowledge and needed to be taught much 
like children. Community forestry, then becomes a context in which neo-liberal notions of appropriate knowledge and the authority that confers to those who are most 'professional' is entrenched into even very remote places of Nepal like Mugu. The high-caste men have appropriated new forms of authority based on written documents and the ability to read them, undermining and devaluing the verbal processes of building consensus that are equally central to the idealised implementation of community forestry.

The structure of community forestry and indeed development discourses in Nepal encourage this kind of dynamic. According to a local, literate informant, when training sessions are given by the DFO they ask for literate members to be sent by the user-group. Some of these training sessions include foreign donor-sponsored all expenses paid tours to other parts of Nepal, a much coveted and rare opportunity for people from Mugu. ${ }^{\mathrm{v}}$ The sessions do not involved reading or writing but literate people are considered more progressive ('aware'), smart and able to learn. While ostensibly sessions to train 'rural villagers' the professionalisation of forestry encourages DFO staff and even the participants themselves to prefer those with a set of recognisable skills and knowledges as evidenced by degrees and levels of literacy. Literacy thus is promoted as a necessary requirement for understanding professional forestry practices and gives privileged access to scientific forestry knowledge, DFO staff and associated opportunities. User-group members then mobilise this discourse of understanding and literacy within decision making forums to exert and resist power. 
Another example illustrates this well. In addition to the operational plan, the map of the forest is similarly considered to be an authoritative, immutable document and the Kamis' lack of literacy used to argue that they were not capable of understanding it. It is upheld as a very important document conferring legal and de facto rights to that land and in many ways symbolises the user-group and its ability to control their land. Thus one Thakuri man said when trying to understand why two influential men had not shown up for a meeting, "We have a map, we have surveyed our forest, Chhatyalbara [nearby village] hasn't. We have a record of the permits we've given. Who else has such a record? ... We have a good management plan. Who else has a good plan?" And he went on to ask why the people who needed to be at the meeting had not come. For him, the map and the plan are symbolic and material representations of the group and because they are good documents, the group should function well. The high-caste people thus appeal to these symbols to try to bring unity in the group and use their ability to read and interpret them to maintain control over the group. This was reflected in the following exchange:

Kami man: Did we build a house in the forest? Others have built houses in the forest.

Thakuri man: If the DFO thinks we have mis-used the forest, he will take it back. We need to do things that won't affect either the little people (sanno manche) or the people with big posts (thulo manche).

Thakuri man \#2: If there's a map, they can't ignore it. Since there is a map of Pipledi [the forest], they can't change it to allow someone to encroach on community forest land. 
Chairman says to the Kamis sitting outside: Don't make a joke, this is a law.

Kamis outside: We haven't cut down the forest. We just built a house. We didn't take timber from the forest.

Later a Thakuri man said: In the minds' of these Dums (untouchables) this map of the forest is only a map, these numbers don't correspond to [real] land (jugga). They think, "where are the numbers on this land (jugga)?" But they have to follow the rules; they need to move the house. (CF meeting 19 June, 1999)

For the high-caste men the map is an extension of the forest. They recognise it as representative of the forest on the ground and in fact almost more 'real' than what's on the ground. The forest can be taken away-and was when the forests were nationalised—but the map can be used for legal challenges now and in the future. It offers some protection from the changing fashions of development and state control. For the Kami men, however, it represents none of these things. They feel under the control of the high-castes and do not see the state as a reliable ally in combating that oppression, especially since the vast majority of all state employees and officials are from the high castes.

The map and the operational plan are direct outcomes of the professionalisation of community forestry. The programme requires that these legal documents are produced and approved by the DFO before the user-group is considered legitimate. The high-caste, literate men seek to maintain good relations with the DFO to further 
their political power and readily adopt and use these symbols of professionalisation and development. Within the user-group they have privileged access to them because of their abilities to read and they use this privilege strategically to maintain control over the user-group process when in fact they do very little forest harvesting. As the 'developed ones' they place themselves in the role of educating the illiterate members (re)producing the assumption implicit in community forestry as a national programme that local users lack the appropriate knowledge to effectively manage and conserve their forests.

The high-caste men must first accept and internalise a neo-liberal discourse that equates illiteracy with backwardness and lack of knowledge to manipulate these discourses in this manner (see also Gupta, 1998, Mahoney and Yngvesson, 1992). While this is not surprising as it serves their interests and articulates with their own understandings of themselves as superior and having rights to dominate the lowercastes, the lower-caste men themselves internalised and manipulated their subjectivity in somewhat different and conflicting ways.

In the dispute over the houses, the Kami men evidently did not believe they needed to be taught and rather used their illiteracy as a counter weapon. On more than one occasion after the rules had been read out loud, the Kami man said essentially, "how do I know what's written there? You could just be pretending to read and say whatever you want." They firmly believed that the user-group could make whatever decision they wanted and it was simply a question of using the right kind of influence within the user-group, influence that did not necessarily depend on literacy. In order to use this kind of counter-weapon, the lower-caste men must first accept the authority 
of the operational plan in order to undermine the Thakuris' reading of it. Thus while it appears that they are resisting the authority of the operational plan and the map--and thus processes of professionalisation--this resistance is only partial. By highlighting their illiteracy, they serve to further legitimate the neo-liberal conflation of knowledge with development (Bondi and Davidson, 2004, Mahoney and Yngvesson, 1992, Larner, 2000).

Their belief that the committee is the real authority was not far off the mark, however, or so it seemed from the treatment of other conflicts including one related to the forest houses. As part of a counter-strategy, the Kamis accused middle-caste Chhetri families of encroaching on the $\mathrm{CF}$ boundaries to create more agricultural land (which they had done). The stipulated fine of Rs. 1,000 is the same as that for building the houses, but the Chhetris who have substantially more social power within the group were able to negotiate for a far lower fine of only Rs. 250. In their case the committee argued that the crime was not as severe because it had occurred on the boundaries of the forest instead of in the middle, and agricultural land was cast as less permanent than a house. More importantly, however, their encroachment had not been reported to the DFO and therefore the committee felt they did not need to impose the Rs. 1,000 fine stipulated by the operational plan. It was also clear from various discussions at the community forestry meetings and more informal conversations that the leadership of the committee did not believe they would be able to collect more than Rs. 250 from the Chhetris, whereas they believed they could force the substantially poorer Kamis to pay the entire fine. 
People of different castes had different opinions about this issue and whether or not it was fair to the Kamis. Many people made reference to the underlying power dynamics and the way that various groups were trying to exert power by either ignoring the rules or enforcing them to the letter. In reference to the large fine given to the Kamis and the much smaller fine given to the Chhetris, one Brahmin man said, "The law needs to be the same for all... if you dig up a little bit of land or a lot, you have dug it up. The Chhetris are influential (thulo manche), they do not do any harm to themselves, and they try to dominate the small and the poor," (interview 25 July, 1999). This same man had suggested during the CF meeting that since the complaint about the houses had been written on one piece of paper that the fine could be applied to them as if it was one case. If so the two men could share the Rs. 1,000 fine. The Chhetris and other Brahmin and Thakuri men, however, argued strongly that the full fine needed to be applied to both of them. It is important to note that not all the highcaste men (women had very little involvement in this issue) were in favour of the way that influence was used in the user-group but they also felt powerless to stop it.

A Kami man who I asked about the issue initially responded by saying that the highercastes dominate the lower-castes and thus the two men were treated unfairly. But when we told him the Chhetris also had to pay a fine, albeit quite a bit less, he said, "Oh, [they] also need to pay? Oh, then it is good. We need to use our own arena, that is good." (interview 13 July 1999). His main concern it seemed, was that the community forestry committee was an arena within which all violators should be punished. He went on to say that the two Kami men knew exactly what they were doing and should not have encroached on the forest to build their houses, "what the committee decided was OK." Here the low-caste man was most concerned about 
oppression of the Kamis through the user-group and not whether the two men had committed a crime. By protesting on these grounds, it is necessary for him to (re)assert that caste defines social hierarchies. He sees this issue as symbolic of the treatment of all lowest-caste people and thus the fine is unjust when only applied to the Kamis. In his mind, provided the Chhetris are also fined, then community forestry is not being used as a mechanism for oppressing the lowest-castes, but rather as an arena for management of the forest. When analysed through this kind of framework, his lack of concern over the amount of the fines is perfectly consistent with his positionality, as what is at stake here for him is whether or not all violators of community rules are punished. It is important to point out, however, that the amount of the fine was significantly linked to caste hierarchies thus I can only conclude that this informant agreed with the assessment by the rest of the user-group that the houses were a more severe crime than the agricultural land.

The most interesting aspect of this episode is the way that people unsettle caste hierarchies through these oppositions to and mobilisations of neo-liberal processes. The higher-castes appropriate the symbols of professionalisation and use their literacy skills to assert their understanding of the community forest rules and the potential legal consequences. The Kami men, in contrast, use their lack of literacy skills in exactly the same way but to resist the domination of the higher-castes. They insist that reading out loud from the operational plan is not sufficient evidence for them because they cannot verify what is written. It is only by accepting their inferior status and lack of understanding, however, that the Kamis are able to mobilise a discourse of ignorance. This kind of strategy requires them to manipulate power relations and the cultural practices of caste with somewhat conflicting results. By making it clear that 
they cannot read the operational plan they accept and publicly reinforce their status as illiterate members. Yet, because they use their lack of literacy as a way to resist the authority of the higher-caste men, they are both contesting the right of the literate to control the group and challenging the idea that the operational plan is the final authority. In these somewhat contradictory ways, they both reinforce and redefine power relations based on caste.

In addition, by making literacy so central to this conflict, literacy is defined as another way in which caste distinctions are maintained, somewhat shifting yet also reinforcing social hierarchies based on caste. It is only those who are ignorant and unaware who are poor, low-caste and thus liable to break community forestry rules and need to be taught proper appreciation for the forest rules. Therefore it is not surprising that the same labels are not applied to the Chhetris, rather it is their educated and powerful status that makes them likely to break community forestry rules and claim impunity. Each caste group draws on these discourses of knowing, awareness, literacy and power to contest the actions of the other members. It is through these processes that the contradictions of neo-liberalism are evident. The strategies of both the high-castes and low-castes serve to further embed ideologies of professionalisation yet there is a simultaneous unsettling and opposition to that.

\section{To market? Relations of poverty, knowledge and power}

Caste relations are deeply entwined with labour relations and it is in this domain that important contradictions of neo-liberalism are also constituted. While markets in Western Nepal are hybrid processes with barter, patron-client and feudal relations continuing to be very important alongside more recognisably capitalist relations, there 
is nevertheless an embedding of a quasi-market logic into these relations. Yet, this embedding is not straightforward or consistent, and hegemonic discourses about poverty, knowledge and power are not always used to exert power. In other cases they are invoked to allow for flexibility and tolerance of rule breaking in community forestry, indicating a level of cohesiveness in the group that contradicts neo-liberal processes. For example, in 1994 a high-caste friend and I observed some Kami men selling firewood in the market town. At that time, it was prohibited to sell firewood to people outside the user-group. I asked my friend why she did not stop them and she replied, “They are poor, what can they do? If they don't sell firewood they can't eat. It is destroying our forest, but what to do?" In this case then, flagrant breaking of CF rules is tolerated because of poverty. Just as in the earlier example, however, mobilising discourses in this way reinforces the caste and wealth distinctions upon which social power and cultural understandings of poverty are based. This kind of mobilisation of discourses of poverty does not serve to destabilise the processes that entrench quasi-market relations into rural societies, but there is also not a direct attempt to exert power. Rather a discourse of poverty is used to allow the Kamis to mitigate their poverty somewhat by selling firewood in opposition to ideologies of competitiveness and individualism.

In fact, the selling of firewood has been very important in changing labour relations based on caste and in this sense has had profound effects on destabilising caste and power relations. As I mentioned above, there has been an increase in wage labour opportunities and these have served to undermine historical relations between the castes. Yet neo-liberal processes do not subsume historical relations completely or generically. Rather antecedents shape the kinds of appropriations and oppositions that 
occur leading to highly uneven and unpredictable outcomes. So while in this instance poverty discourses are not used to exert power, in an indirect way, they serve to afford the Kamis with more power. Very poor high-caste people do not and socially could not sell firewood to mitigate their poverty because it would reduce their social status (see also Gidwani, 2000). High-caste men in particular but also women are very reluctant to engage in activities that are considered the domain of the low-castes and therefore leave the quite significant economic opportunity to sell firewood to the lowest-castes. This kind of rejection of lucrative opportunities defies a strict market logic. Through such material practices, both the low-caste and high-caste people (re)produce the symbolic meaning of work associated with caste. Yet by perpetuating these discourses about work, the Kamis are afforded the opportunity to change their economic impoverishment even if symbolically they are 'poor' because they are lowcaste and sell firewood. Poverty and caste continue to be reproduced as important social distinctions albeit to destabilise somewhat the economic but not symbolic foundations upon which social power is exerted.

Similarly, members of the user-group assert their knowledge of forest management in different ways that do not necessarily follow the kind of pattern expected from the account I've given so far, although when understood as enacting subjectivities and embedded within new, partial appropriations and oppositions to neo-liberal processes, it is consistent. The high-caste men who control the user-group committee describe how community forestry has taught them everything they know about managing the forest. One Thakuri man said, “At the beginning we didn't know anything... One day [the DFO] asked all us janne manche (literate, knowledgeable people-literally 'going somewhere people') if we wanted to take our forest. We didn't understand, 
but he spoke to our older brother (a village leader) and he said, 'OK, we do not understand, but we are ready to try it." "In another informal discussion, a Brahmin man told me that community forestry had taught them all they know about managing the forest. Here literate, powerful men are portraying themselves in much the same light as they portray the Kamis.

Women mainly of the higher-castes, however, are insistent that they had important knowledge about managing the forest. Women do most of the harvesting of firewood, fodder and leaf litter thus they have extensive knowledge of these resources and the logistics of managing their collection (Nightingale, forthcoming). A Thakuri woman said it this way, "Long before, when our forest had become degraded, we had the idea [to protect it]. Then we heard on the radio about other places...three rangers and [high-caste Thakuri men-village leaders] got together and decided to form the community forest." (interview 20 Feb 1999). A Chhetri woman, after saying that she had been afraid and did not really understand what community forestry would be, asserted, "The men gave their wives a lot of trouble. The men didn't know how to manage the firewood, they wanted to have permits for that too. The first time that they wanted to do this, the women [of all three villages]... scolded their husbands." (interview 14 June 1999). Other women also talked about how they had prevented the men from trying to regulate firewood and leaf litter with permits-resources that are collected almost daily — arguing that it was unrealistic to try to insist on permits for such things. Here, the women, in contrast to the men, assert that their knowledge is important, yet at the same time they also talk about how they did not understand community forestry and if it had not been for the vision of a few high-caste men who are village leaders, they would not have tried it. One Brahmin woman said, "[In the 
beginning] when we were in community forestry meetings, the men would applaud the things the women said. They thought our ideas were good. The men were educated (parde-lekeko) and we were not, so we needed both men and women for the community forest." (interview 20 Feb 1999). In this example, the women are quite clear about the importance of their contributions, but they contrast these contributions with the educated knowledge of the men. Similarly, the men contrast their knowledge — or lack of it—in relation to the professional knowledge of the DFO staff.

As in the example of selling firewood, the use of these contrasting discourses does not map easily onto social and power relations, unless one understands that the mobilisation of these discourses is possible only by accepting the subjectivities of caste, gender and literacy and the power they confer on one. The high-caste men accept the dominance and knowledge of the experts and they utilise a discourse of ignorance to demonstrate to me how developed they are because they have followed the way shown to them by professionals. This helps illustrate the extent to which ideologies of neo-liberalism have been internalised within remote parts of rural Nepal. The professionalisation of forestry and its origins outside of Nepal are especially evident in the following quote. When asked how community forestry was started, a Brahmin man replied, "Until 2034 (1977) all the forests were national forests. Then scientists, specialists, and scholars came from different countries and thought that the forest was for the people, and it is better to give the right to the people to conserve their own forest." (interview 12 June 1999). In fact, he is basically right as community forestry was initiated by the World Bank, FAO and the World-wide Fund for Nature although there were important inputs from Nepalis as well, most of whom had been educated abroad. There is quite a lot at stake here for these men in Mugu 
beyond their desire to manage the forest effectively. They need to convey to the outside world (through me and my writing) that they have learned how to manage their forests 'properly' and properly is defined as scientific forestry as taught by the DFO staff. In addition, by giving deference to the DFO staff, they hope to gain political favour that can benefit them in a variety of ways locally and even nationally. Furthermore, they are keen to demonstrate that they follow the prescriptions of community forestry to legitimate their control over the committee. Finally, because these men are known to be educated and 'aware', at a fundamental level they do not need to prove that to me. In many ways, being 'aware' means that they are able to learn from experts and therefore it is not necessary to assert their knowledge.

The women, however, have entirely different positionalities and this opens up the possibility for them to insist on the importance of their knowledge. The women generally don't have much interaction with the DFO staff and therefore are not as keen to position themselves favourably in relation to them. More importantly, because they know they are uneducated, they do not need to negate their own skills and knowledge to assert that they are 'aware'. While both men and women saw me and my work as potentially legitimating their claims, the women were keen to insist that they do have knowledge even if they do not have literacy. This insistence does not disrupt the hierarchies produced by literacy — they say that because they are illiterate the men are needed in community forestry—but it does disrupt the idea that literate knowledge is sufficient for forest management. This assertion contests but does not undermine the professionalisation of community forestry and the literate knowledge upon which such claims are based. 


\section{The professionalisation of forest care}

Professionalisation in community forestry does not only occur symbolically and in relation to control over the management process, it also occurs in relation to active management. By active management I mean activities like thinning, pruning and seedling rearing. It is a critical part of both the transmission of knowledge from the DFO to the user-group and the user-group's sense of conserving their forest. Thinning and pruning was taught by the DFO at a training session I attended in 1994 and five others have been conducted district-wide since that time. The training was required for at least one member of each household and had participation from a broad cross section of the user-group, people of all castes and both men and women. It was done in the forest controlled by the user-group described here, although people were present from other user-groups as well. The DFO worked along side the villagers and made it clear to me and the others that he had expert knowledge. He scolded the women for focusing too much on collecting firewood ${ }^{\mathrm{vi}}$ instead of trimming off the young, green branches of the saplings and explained carefully to everyone how it was to be done.

The user-group now has a small demonstration plot (less than 1 hectare) that they have thinned and pruned. Interestingly, the stand is just outside the boundary of the community forest proper. It is shown-off during district-wide training sessions as an example of what a forest can look like. The trees are relatively even-aged blue pines, regularly spaced with virtually no under-story growth. It is emblematic of the western, professional forestry bias in community forestry that promotes the growth of mono-culture stands of timber species over other forest products (Häusler, 1993). The objectives of thinning and pruning are to allow the remaining trees to grow faster in 
the absence of competition for light and nutrients which will maximize eventual yield of timber (Wenger, 1984). Raymond Borgen, a forester who worked with me during the fieldwork, believes that the work they are doing is inadequate and therefore not necessary. The pruning of lower branches is the focus of their work, but these branches would self-prune as the forest develops. They do not appear to be thinning (removing whole saplings), but even if they have cut some, they are not removing nearly enough. In Borgen's opinion, the demonstration stand is still far too thick to accomplish these objectives. As a consequence, the stand will not grow great timber nor does it provide for any other kinds of forest products except some firewood from pruned branches.

The user-group has incorporated these 'scientific' ideas of good forest management and show off the demonstration stand as evidence of their care for and knowledge of forestry. Yet, these activities can not produce the kind of forest they really want and need. Already there are conflicts brewing within the user-group over the amount of grazing land available and the fire suppression policy that reduces understory foliage good for grazing. Scientific forestry was developed in Germany and the United States to produce timber for industry and while in many places this kind of forestry is being re-thought, the forestry practices advocated in Nepal are still rooted in older models of forest dynamics (Alverson et al., 1994, Scott, 1998, Wenger, 1984). The management techniques promoted by the DFO are thus intended for the production of timber, not multi-species, multiple resource 'subsistence' harvesting such as that done in Nepal. Perhaps fortunately, the thinning and pruning activities are done on such a small scale that they will have little impact on the forest as a whole unless the effort intensifies. Nevertheless, professionalisation of forestry in Nepal and the ways in which such 
practices and knowledges are transmitted and incorporated into community forestry user-groups all across Nepal potentially has serious ramifications for producing the kinds of forest ecosystems necessary for survival.

\section{Conclusion:}

Community forestry is a highly complex arena for the entrenchment of neo-liberalism. The programme itself is oriented around collective values which in many ways are in direct opposition to neo-liberal values. Collectively owned and managed forests belie the individualistic and private property ideologies that are considered emblematic of neo-liberalism. Yet despite this opposition, the programme is quickly becoming enrolled in various neo-liberal processes. I have explored here how the professionalisation of forestry knowledge and practice has intersected with antecedent social relations and forestry practices to provide new avenues for resisting and appropriating power. The case study demonstrates how people exploit the artificial distinction between professional and local knowledges to claim authority and exert power and resistance. These processes are not clean and universal as neo-liberalism is often portrayed, rather they are shaped by the contexts through which they are invoked and the contestations of them that occur within the daily functioning of usergroups. This case emphasises the incomplete and unpredictable outcomes of neoliberal processes and the ways in which they are increasingly becoming embedded within development practices that in many ways were designed to counter such trends.

To return to the three key objectives of community forestry that are undermined, the overall devaluing of so-called local knowledge potentially has serious ramifications for forest ecosystems and community forestry. Scientific forestry cannot produce the 
kind of forests and resources people need for daily survival in Nepal because the kind of scientific forestry taught in Nepal is not designed to produce multi-use forests. Already the effects of this are becoming evident in Mugu and how the user-group will respond to this change in their forest is unclear. More dialog is needed between usergroups and their (sometimes conflicting) needs and the DFO to tailor management priorities to the needs of each group, drawing from the rich locally embedded ecological knowledge of forest users.

Secondly, the symbolic ways in which only literate people are considered legitimate forest managers serves to effectively exclude the poorest of the poor from the community forestry management process. But more significantly, it defines forest management as separate from forest harvesting and the daily practices of resource use. It is only by making that symbolic shift that the knowledge of those who use the forest most often-illiterate, low-caste men and women of all castes — can be dismissed as inadequate for understanding community forestry. Thus it was considered inappropriate for the women to be gathering firewood during the pruning and thinning exercise, rather than seeing the potential for firewood collection as a means of thinning the forest. Through these processes and from the examples I have given, it is clear that the focus on scientific knowledges and development within community forestry undermine the ability of the programme to promote democratic access to forest management processes because of the way that some users are marginalised. Fundamentally, all villagers need to be seen to already have important knowledge about forest management that can be supported by community forestry, rather than community forestry teaching them to care for their resource. 


\section{References}

Adams, W. M. (1990) Green Development, Routledge, New York, NY.

Agrawal, A. and Sivaramakrishnan, K. (2000) Introduction: Agrarian Environments. In Agrarian Environments: Resources, Representation and Rule in India, (Eds, Agrawal, A. and Sivaramakrishnan, K.) Duke University Press, Durham, pp. $1-22$.

Alverson, W. S., Kuhlmann, W. and Waller, D. M. (1994) Wild Forests: Conservation Biology and Public Policy, Island Press, Washington, DC.

Arnold, J. E. M. (1998) Managing Forests as Common Property, Food and Agriculture Organization of the United Nations, 67.

Bhattarai, K., Conway, D. and Shrestha, N. (2002) The Vacillating Evolution of Forestry Policy in Nepal. International Development Planning Review, 24, 315-338.

Bondi, L. and Davidson, J. (2004) Troubling the Place of Gender. In Handbook of Cultural Geography, (Eds, Anderson, K., Domosh, M., Pile, S. and Thrift, N.) Sage, London.

Butler, J. (1990) Gender Play: feminism and the subversion of identity, Routledge, New York.

Butler, J. (1992) Contingent Foundations: Feminism and the Question of "Postmodernism". In Feminist Theorize the Political, (Eds, Butler, J. and Scott, J.) Routledge, London, pp. 3-21.

Butler, J. (1997) The Psychic Life of Power, Stanford University Press, Stanford.

Crush, J. (1995) Introduction: Imagining Development. In Power of Development, (Ed, Crush, J.) Routledge, New York, pp. 1-26.

de Janvry, A. (1981) The Agrarian Question and Reformism in Latin America, John's Hopkins' University Press, Baltimore.

Escobar, A. (1995) Encountering Development: The Making and Unmaking of the Third World, Princeton University Press, Princeton, NJ.

Gidwani, V. (2000) Labored Landscapes: Agroecological Change in Central Gujarat, India. In Agrarian Environments: Rule, Resources and Representations in India, (Eds, Agrawal, A. and Sivaramakrishnan, K.) Duke University Press, Durham.

Gilmour, D. A. and Fisher, R. J. (1991) Villagers, Forests and Foresters: The Philosophy, Processes and Practice of Community Forestry in Nepal, Sahayogi Press, Kathmandu.

Graner, E. (1997) The Political Ecology of Community Forestry in Nepal, Verl. für Entwicklungspolitik, Saarbrücken.

Gupta, A. (1998) Postcolonial Developments: Agriculture in the Making of Modern India, Duke University Press, Durham and London.

Gururani, S. (2000) Regimes of Control, Strategies of Access: Politics of Forest Use in the Uttarakhand Himalaya, India. In Agrarian Environments: Resources, Representation and Rule in India, (Eds, Agrawal, A. and Sivaramakrishnan, K.) Duke University Press, Durham and London, pp. 170-190.

Hart, G. (2002) Geography and Development: Development/s beyond neoliberalism? Power, Culture and Political Economy. Progress in Human Geography, 26, 812-822.

Häusler, S. (1993) Community Forestry: A Critical Assessment. The Case of Nepal. The Ecologist, 23, 84-90. 
Hoftun, M., Raeper, W. and Whelpton, J. (1999) People, Politics and Ideology: Democracy and Social Change in Nepal, Mandala Book Point, Kathmandu.

Jessop, B. (2002) Liberalism, Neoliberalism, and Urban Governance: A StateTheoretical Perspective. Antipode, 34, 452-472.

Larner, W. (2000) Neo-liberalism: Policy, Ideology, Governmentality. Studies in Political Economy, 63, 5-25.

Laurie, N., Andolina, R. and Radcliffe, S. (2003) Indigenous Professionalization: Transnational Social Reproduction in the Andes. Antipode, 35, 463-491.

Mahoney, M. A. and Yngvesson, B. (1992) The Construction of Subjectivity and the Paradox of Resistance: Reintegrating Feminist Anthropology and Psychology. Signs, 18, 44-73.

Mansfield, B. (2004) Neoliberalism in the oceans: "rationalization," property rights, and the commons question. Geoforum, 35, 313-326.

Mehta, A. and Bondi, L. (1999) Embodied Discourse: on gender and fear of violence. Gender, Place and Culture, 6, 67-84.

Messerschmidt, D. A. (1987) Conservation and Society in Nepal: Traditional Forest Management and Innovative Development. In Lands at Risk in the Third World: Local-Level Perspectives, (Eds, Little, P. D., Horowitz, M. M. and Nyerges, A. E.) Westview Press, Boulder, pp. 373-397.

Nightingale, A. (forthcoming) The Nature of Gender: work, gender and environment. Environment and Planning D: Society and Space.

Ostrom, E. (1992) The Rudiments of a Theory of the Origins, Survival, and Performance of Common-Property Institutions. In Making the Commons Work: Theory, Practice, and Policy, (Ed, Bromley, D.) ICS Press, San Francisco.

Peck, J. and Tickell, A. (2002) Neoliberalizing Space. Antipode, 34, 380-404.

Pigg, S. L. (1996) The Credible and the Credulous: The Question of "Villagers' Beliefs" in Nepal. Cultural Anthropology, 11, 160-201.

Rankin, K. N. (2001) Governing development: neoliberalism, microcredit, and rational economic woman. Economy and Society, 30, 18-37.

Rankin, K. N. (2004) The Cultural Politics of Markets: Economic Liberalization and Social Change in Nepal, Pluto Press, London.

Scott, J. C. (1998) Seeing Like a State: How Certain Schemes to Improve the Human Condition Have Failed, Yale University Press, New Haven.

Shrestha, M. L., Joshi, S. P., Bhuju, U. R., Joshi, D. B. and Gautam, M. (1995) Community Forestry Manual, HMG Ministry of Forests and Soils Conservation, Kathmandu.

Sivaramakrishnan, k. and Agrawal, A. (2003) Regional Modernities: The Cultural Politics of Development in India, Stanford University Press, Stanford.

Watts, M. (2003) Development and Governmentality. Singapore Journal of Tropical Geography, 24, 6-34.

Wenger, K. F. (Ed.) (1984) Forestry Handbook, Wiley, New York.

\footnotetext{
${ }^{\mathrm{i}}$ In 1957 all the forests in Nepal were brought under control of the Ministry of Forests and with the exception of a few private forests, all forested land was considered property of the state. This served to undermine some local systems of forest management, but in other places, led the evolution of new local systems (Messerschmidt, 1987)

${ }^{\text {ii }}$ Since I left the field in late 1999 Maoist groups operating in western Nepal have periodically disrupted affairs in Mugu. The latest reports I have are that the Maoists do not have a permanent presence (they do in Jumla, two days walk to the south) but do demand food and support when they
} 
come through. In Jumla, the Maoists have undermined community forestry user-groups and intimidated foreign-aid sponsored staff trying to promote CF. I do not know what the situation is in Mugu but have good reason to suspect that even if officially the group has been disrupted, that it continues to operate informally.

${ }^{\text {iii I }}$ believe the foreign-donor sponsored offices that were established in Mugu in the late 1990s including the Karnali Local Development Project (KLDP) and have closed their offices due to Maoist disruptions.

${ }^{\text {iv }}$ Gender relations are also being re-configured and contested in ways that are embedded within and similar to caste relations. In this paper I focus on caste largely because the particular ethnographic events I describe were mainly contestations of caste. See (Nightingale, forthcoming) for an analysis of the intersections of gender and caste.

${ }^{\mathrm{v}}$ These training sessions are the only direct support given to villagers in this region for community forestry. The donors also sponsor training for District Forest Office staff. In other parts of the country, foreign donors provide more intensive direct support to user-groups. Staff members attend user-group meetings, help resolve disputes and utilise various 'community mobilisation' strategies.

${ }^{\text {vi }}$ One woman said to the others that she wasn't going home without firewood after walking that far into the forest. She considered it a wasted trip otherwise. 